\title{
In Vitro Propagation of Temulawak (Curcuma xanthorrhiza Roxb.)
}

\author{
Authors \\ Samanhudi ${ }^{1,{ }^{*}}$, Ahmad Yunus $^{1}$, Bambang Pujiasmanto ${ }^{1}$, Anindya Saras ${ }^{2}$ \\ Afiliation \\ ${ }^{1}$ Lecturer Staff at Faculty of Agriculture, Sebelas Maret University \\ ${ }^{2}$ Undergraduate Student of Faculty of Agriculture, Sebelas Maret University
}

\section{Keyword \\ O Temulawak \\ - Curcuma xanthorrhiza \\ $\ni$ IBA \\ $\vartheta$ BAP \\ $\partial$ In vitro}

Received 7 September 2015 Revised 25 November 2016 Accepted 16 June 2017

*Corresponding author Samanhudi JI. Ir. Sutami 36A, Surakarta, Indonesia 57126 samanhudi@ymail.com

\section{ABSTRACT}

Problems encountered in the development of herbal medicine industry is that most of the raw materials $(80 \%)$ came from the forest or natural habitats and the rest $(20 \%)$ of the results of traditional cultivation. The research is focused to get the propagation techniques of temulawak by in vitro using various combinations of IBA and BAP concentration, each consisting of $0,1,2,3,4 \mathrm{ppm}$. The purpose of this research is to gain a plant propagation technique of temulawak through the use of IBA and BAP concentration so as to provide a quality seeds. The results showed that the highest shoots obtained at 1 ppm IBA and 3 ppm BAP treatment with a buds height of $15.9 \mathrm{~cm}$. Treatment of 0 ppm IBA and 4 ppm BAP produces the highest buds number by 4 buds. While the highest number of leaves obtained in $2 \mathrm{ppm}$ IBA and 3 ppm BAP treatment with total of 18 leafs. The highest length of leaf obtained in the treatment of $3 \mathrm{ppm}$ IBA and $2 \mathrm{ppm}$ BAP with a length of $14.6 \mathrm{~cm}$. Variable highest number of roots was obtained at treatment of $4 \mathrm{ppm} \mathrm{IBA}$ and $1 \mathrm{ppm}$ BAP with root number exceeds 30 pieces with very many hair roots and the highest root length was obtained at treatment of $2 \mathrm{ppm}$ IBA and 0 ppm BAP with a length of $15.6 \mathrm{~cm}$. Based on these results it can be concluded that the IBA and BAP treatment at various concentrations can affect the propagation and growth of temulawak explants.

\section{INTRODUCTION}

Temulawak or Java turmeric is an Indonesian native medicinal plant, known to has many benefits for treating many diseases, included possess cytotoxic effects on breast cancer cells (Musfiroh et al. 2013), exhibit of antioxidant, anti-inflammatory, antimicrobial, and anticarcinogenic activities, hepato- and nephro-protective, antirheumatic, and hypogyicemic effects (Anand et al. 2007; Hwang dan Rukayadi 2006), anticancer, antimicrobials, and anti-inflammatory (Oon et al. 2015), migraines, constipation, liver complaints and inflammatory conditions (Devaraj et al. 2013), and anti-hyper cholesterolaemic (Aznam and Atun 2016). 
As the era develop many people are more aware about health and returned to use traditional medicine. Therefore, increase the demand of Java turmeric has impact on continuous and availability of planting material. As a medicinal raw material for most of traditional medicine in Indonesia, the java turmeric itself should have fulfill the high quality requirement includes quality, safety and efficacy (BPOM 2005). Approximately $70 \%$ of herbal medicine on Indonesia's market contains java turmeric and $70 \%$ of the production medicine is exported overseas, these condition provide opportunities for farmers as provider of the raw material (Bermawie et al. 2006). On the other hand, an efficient technology of java turmeric propagation is limited and needs to be developed (Rahayu and Adil 2012). It takes technology to propagate java turmeric in a relatively short time and pest-diseases free such as tissue culture technology.

Tissue culture according to Hendaryono and Wijayani (1994) means to cultivate plant tissue into a new living plant and has a same characteristic like its parent. The probability of success on in vitro propagation depends by various factor including the type of media, $\mathrm{pH}$, light, temperature and growth regulator. On in vitro propagation, auxin (IBA) and cytokinin (BAP) are the most common plant growth regulator used to help the tissue to develop rapidly and propagate quickly. IBA is a plant growth regulator which belongs to the group of auxin, it stimulates root growth, increasing germination, etc. Another plant growth regulator that is also commonly used for in vitro propagation is BAP which belongs to the group of cytokinin. BAP used to induced cell differentiation, induced leaves formation and shoot multiplication. The combination of BAP and IBA are expected to be able stimulates shoot growth of java turmeric.

The objective of this research was to observe the response of java turmeric as it given auxin (IBA) and cytokinin (BAP) on in vitro shoot propagation. The results of this research are expected to be reference in developing in vitro regeneration of java turmeric. As the research develop, there will be effective to provide the raw material of java turmeric and fulfill market needs.

\section{METHODS}

This research conducted at Laboratory of Biotechnology and Tissue Culture, Sebelas Maret University in Surakarta. Shoot from rhizome of java turmeric with at least $5 \mathrm{~cm}$ in length were used as a explants. These explants were cultured on MS media (Murashige and Skoog, 1962) added with $\operatorname{IBA}(0,1,2,3$, $4 \mathrm{mg} / \mathrm{l})$ and $\operatorname{BAP}(0,1,2,3,4 \mathrm{mg} / \mathrm{l})$ it becomes 25 treatments with 3 replication, the total samples are 75 explants. For about $20 \mathrm{ml}$ of media poured into each bottle culture and covered. Sterilizing the media with autoclave for about 1 hour includes drying. The media were placed in culture room racks with $26-28^{\circ} \mathrm{C}$ air temperature, media can be used until 3 days storage to make sure there are no contamination and perfect thickens.

The research was arranged in a Fully Randomized Design with 25 treatments and 3 replications. Data analysis was performed using Annova (test F) with a $5 \%$ significance level to test the treatment effect and DMRT 5\% to test the average difference in treatment. Variables observations were shoot emerged time, shoot number, shoot height, root emerged time, root number, root length.

\section{RESULTS AND DISCUSSION}

There were no significantly different effects among treatments about IBA and BAP combinations except for time emerged shoot on the other variable observed. IOB3 and I1B3 significantly different for time emerged shoot than the rest of the treatments. In general, adding BAP into the media could provide the best effect on all growth components of Java turmeric shoot explant (Rahayu and Adil 2012). The most appropriate combination of treatments to induced shoot is IOB2 (BAP $2 \mathrm{mg} / \mathrm{l}$ ) with the average of time emerged shoot is 6 days. It is suit Madhulatha et al. (2004) research that BAP are known to induced both axillary and adventitious shoots formation from meristematic explants. For IOB3 and I1B3 proves that the used of BAP ( $3 \mathrm{mg} / \mathrm{I}$ ) are reducing the time emerged for shoot.

There were no significantly different effects among treatments about IBA and BAP combinations except for time emerged shoot on the other variable observed. IOB3 and I1B3 significantly different for time emerged shoot than the rest of the treatments. In general, adding BAP into the media could provide the best effect on all growth components of Java turmeric shoot explant (Rahayu and Adil 2012). The most appropriate combination of treatments to induced shoot is IOB2 (BAP $2 \mathrm{mg} / \mathrm{l}$ ) with the average of time emerged shoot is 6 days. It is suit Madhulatha et al. (2004) research that BAP are known to induced both axillary and

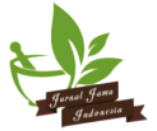


Table 1 Effect of IBA and BAP on time emerged shoot, root and leaf in regeneration of Java Turmeric

\begin{tabular}{|c|c|c|c|}
\hline \multirow[t]{2}{*}{ Treatments } & \multicolumn{3}{|c|}{ Days average (HST) } \\
\hline & Shoot & Root & Leaf \\
\hline IOBO & $10.7 a$ & $12.7 a$ & $32 a$ \\
\hline IOB1 & $9.3 a$ & $5 a$ & $23.3 a$ \\
\hline IOB2 & $6 a$ & $7 a$ & $16 a$ \\
\hline IOB3 & $26.3 b$ & $9 a$ & $28.3 a$ \\
\hline IOB4 & $7 a$ & $6.7 a$ & $22.7 a$ \\
\hline I1B0 & $10.7 a$ & $17.7 a$ & $28.3 a$ \\
\hline I1B1 & $8.7 a$ & $5 a$ & 19.3a \\
\hline I1B2 & $10.7 a$ & $4 a$ & $20.3 a$ \\
\hline I1B3 & $18.3 b$ & $6.7 a$ & $22.3 a$ \\
\hline I1B4 & $9.7 a$ & $5.7 a$ & $12 a$ \\
\hline 12BO & $8.3 a$ & $7.7 a$ & $20 a$ \\
\hline 12B1 & $15.70 \mathrm{a}$ & $4.70 a$ & $22.7 a$ \\
\hline 12B2 & $13 a$ & $9.3 a$ & $26.3 a$ \\
\hline 12B3 & $18 a$ & $4.7 a$ & $23.3 a$ \\
\hline 12B4 & $9 a$ & $5 a$ & $17.7 a$ \\
\hline I3B0 & $12.7 a$ & $12.7 a$ & $27 a$ \\
\hline I3B1 & $11.3 a$ & $8 a$ & $20.3 a$ \\
\hline 13B2 & $13.7 a$ & $4.7 a$ & $27.3 a$ \\
\hline 13B3 & $16.3 a$ & $5.3 a$ & $27.3 a$ \\
\hline 13B4 & $7 a$ & $9 a$ & $23 a$ \\
\hline 14BO & $10 a$ & $6.3 a$ & $15.7 a$ \\
\hline 14B1 & $9.7 a$ & $9 a$ & $24 a$ \\
\hline 14B2 & $6.30 a$ & $15 a$ & $21.7 a$ \\
\hline 14B3 & $11.7 a$ & $10.7 a$ & $24.3 a$ \\
\hline I4B4 & $11 a$ & $7.7 a$ & $26 a$ \\
\hline
\end{tabular}

Values followed by the same letter in the same column are not significant different according to DMRT at $5 \%$ level.

adventitious shoots formation from meristematic explants. For IOB3 and I1B3 proves that the used of BAP $(3 \mathrm{mg} / \mathrm{l})$ are reducing the time emerged for shoot.

The root number and leaf number are significantly different except for shoot number. There is an equally distribution of data for leaf number and root number. Maximum number of root per explant was found from I4B4 with 32.33 average. It proves that the combination with IBA $4 \mathrm{mg} / \mathrm{l}$ and BAP $4 \mathrm{mg} / \mathrm{l}$ was the best treatment for number of root. Rabbani et al. (1996) found that $5 \mathrm{mg} / \mathrm{l}$ BAP was the best concentration for number of root per plantlets. So, root number per plantlet increased with the increase of BAP concentration and decreased in the lower concentration. Among the treatments 12B3 showed maximum number of leaves per plantlet. It produces 14.33 leaves per plantlet in IBA $2 \mathrm{mg} / \mathrm{l}$ and BAP $3 \mathrm{mg} / \mathrm{l}$.
All treatment that given for number of leaves was found significant. In general, the numbers of the root and the leave on media containing IBA and BAP both alone or in combination showed positive response.

Number of shoot was showed not significantly different as it given treatments. In this case, growth regulator auxin concentration of $0,1,2,3$ and $4 \mathrm{mg} / \mathrm{l}$ not be able yet to increase growth. This condition alleged to be caused plant contained endogenous auxin and it is sufficient so that exogenous auxin that be given has not significantly different (Patma et al. 2013). From the results of statistical analysis showed that the interaction between IBA and BAP has not significantly affected the parameter observation. This condition showed that the media treatment and the provision of IBA and BAP has the almost same response. 
Table 2 Effect of IBA and BAP on time emerged shoot, root and leaf in regeneration of Java Turmeric

\begin{tabular}{|c|c|c|c|}
\hline \multirow[t]{2}{*}{ Treatments } & \multicolumn{3}{|c|}{ Days average (HST) } \\
\hline & Shoot & Root & Leaf \\
\hline IOBO & $12.33 a$ & $6.33 a$ & $1.00 a$ \\
\hline IOB1 & $7.67 a$ & $2.33 a$ & $1.00 a$ \\
\hline IOB2 & $8.67 a$ & $3.67 a$ & $1.67 a$ \\
\hline IOB3 & $9.67 a$ & $3.00 \mathrm{a}$ & $1.33 a$ \\
\hline IOB4 & $13.33 a$ & $8.00 b c$ & $2.00 a$ \\
\hline I1B0 & $9.67 a$ & $3.33 a$ & $1.33 a$ \\
\hline I1B1 & $7.33 a$ & $3.33 a$ & $1.67 a$ \\
\hline I1B2 & $23.67 d$ & $8.00 \mathrm{bc}$ & $1.33 a$ \\
\hline I1B3 & $21.33 c$ & $6.67 a$ & $1.67 a$ \\
\hline I1B4 & $14.00 a$ & $7.67 a$ & $1.67 a$ \\
\hline 12BO & $19.00 b c$ & $9.00 c$ & $1.67 a$ \\
\hline 12B2 & $17.00 a$ & $13.00 \mathrm{c}$ & $1.67 a$ \\
\hline 12B3 & $15.67 a b$ & $14.33 c$ & $2.00 a$ \\
\hline 12B4 & $16.67 a$ & $6.00 \mathrm{~b}$ & $1.00 a$ \\
\hline I3B0 & $16.00 a$ & $7.67 b$ & $1.00 a$ \\
\hline I3B1 & $27.67 d$ & $7.67 b$ & $1.67 a$ \\
\hline 13B2 & $32.33 d$ & $8.00 b c$ & $2.00 a$ \\
\hline 13B3 & $31.33 d$ & $9.67 c$ & $2.00 a$ \\
\hline 13B4 & $22.00 \mathrm{~cd}$ & $7.00 \mathrm{a}$ & $1.33 a$ \\
\hline 14B0 & $23.33 d$ & $6.33 a$ & $1.33 a$ \\
\hline 14B1 & $28.33 d$ & $8.33 c$ & $1.33 a$ \\
\hline 14B2 & $13.67 a$ & $6.67 a$ & $1.67 a$ \\
\hline 14B3 & $14.33 a$ & $5.00 \mathrm{a}$ & $2.00 a$ \\
\hline 14B4 & $32.33 d$ & $7.67 a$ & $1.67 a$ \\
\hline I1B2 & $23.67 d$ & $8.00 \mathrm{bc}$ & $1.33 a$ \\
\hline I1B3 & $21.33 c$ & $6.67 a$ & $1.67 a$ \\
\hline
\end{tabular}

Values followed by the same letter in the same column are not significant different according to DMRT at $5 \%$ level.

Table 3 showed there were significantly different except for root length. The maximum root length was $15.4 \mathrm{~cm}$ in I2B4 treatment. The combination between IBA $2 \mathrm{mg} / \mathrm{l}$ and BAP $4 \mathrm{mg} / \mathrm{l}$ gives the best root length. According to Indah and Ermavitalini (2013) the addition of exogenous auxin and cytokinin changed the concentration of endogenous growth regulator inside the tissue. So, IBA $2 \mathrm{mg} / \mathrm{l}$ and BAP $4 \mathrm{mg} / \mathrm{l}$ are compatible with endogenous hormone inside the plant. On the other hand the rest of the treatment doesn't seem to compatible on variable shoot height and leaves length. The plant growth regulator is possible not be able to increace shoot height and leaves length because of explant has a low content if endogenous hormone and it needed more exogenous hormone to the culture medium and the treatments given of IBA and BAP doesn't seem affected much.

As for the shoot height, the culture bottle has the same height in each treatments and replication and it has the same condition were the plantlet observe. So, it is reasonable when the shoot height has the same value. Because, the bottle that we used is the same height and for the java turmeric grow in the same pattern in 2 months it can reach the cover of the bottle in every treatments that been given.

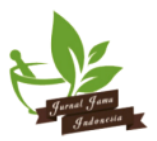


Table 3 Effect of IBA and BAP on shoot height, root length and leaves length of regeneration Java turmeric

\begin{tabular}{|c|c|c|c|}
\hline \multirow[t]{2}{*}{ Treatments } & \multicolumn{3}{|c|}{ Days average (HST) } \\
\hline & Shoot & Root & Leaf \\
\hline IOBO & $8.85 a$ & $3.80 a$ & $4.40 a$ \\
\hline IOB1 & $15.00 \mathrm{~b}$ & $3.00 a$ & $7.50 a$ \\
\hline IOB2 & $12.25 b$ & $5.50 a$ & $9.05 a$ \\
\hline IOB3 & $5.50 a$ & $4.50 a$ & $8.50 a$ \\
\hline IOB4 & $12.25 a$ & $3.75 a$ & $6.95 a$ \\
\hline I1BO & $9.67 a$ & $3.97 a$ & $9.50 a$ \\
\hline I1B1 & $16.00 \mathrm{~b}$ & $4.00 a$ & $7.00 a$ \\
\hline I1B2 & $15.60 \mathrm{~b}$ & $7.50 a$ & $10.50 a$ \\
\hline I1B3 & $15.90 b$ & $10.35 a$ & $10.00 a$ \\
\hline I1B4 & $10.70 a$ & $2.40 a$ & $11.50 a$ \\
\hline 12BO & $12.63 a$ & $11.17 \mathrm{a}$ & $10.70 a$ \\
\hline I2B1 & $12.10 a$ & $12.45 \mathrm{a}$ & $12.50 \mathrm{a}$ \\
\hline 12B2 & $17.00 \mathrm{~b}$ & $10.00 \mathrm{a}$ & $10.47 a$ \\
\hline 12B3 & $14.00 \mathrm{~b}$ & $5.00 a$ & $13.50 a$ \\
\hline 12B4 & $14.00 \mathrm{~b}$ & $15.40 \mathrm{~b}$ & $8.23 a$ \\
\hline I3BO & $12.50 \mathrm{a}$ & $10.00 \mathrm{a}$ & $14.50 \mathrm{a}$ \\
\hline I3B1 & $16.00 \mathrm{~b}$ & $2.00 a$ & $10.03 a$ \\
\hline 13B2 & $15.00 \mathrm{~b}$ & $6.8 a$ & $15.50 a$ \\
\hline 13B3 & $14.00 \mathrm{~b}$ & $5.50 a$ & $11.40 a$ \\
\hline 13B4 & $13.10 b$ & $15.00 \mathrm{a}$ & $16.50 a$ \\
\hline 14B0 & $13.20 \mathrm{~b}$ & $7.00 a$ & $9.43 a$ \\
\hline I4B1 & $15.50 \mathrm{~b}$ & $9.40 a$ & $17.50 a$ \\
\hline 14B2 & $13.00 \mathrm{~b}$ & $6.10 a$ & $5.00 a$ \\
\hline 14B3 & $13.20 b$ & $3.40 a$ & $18.50 a$ \\
\hline I4B4 & $11.00 \mathrm{a}$ & $11.1 \mathrm{a}$ & $14.00 \mathrm{a}$ \\
\hline
\end{tabular}

Values followed by the same letter in the same column are not significant different according to DMRT at $5 \%$ level.

\section{CONCLUSION}

Based on the results of this present study it can be concluded that the treatment of IBA and BAP just affected number of root, number of leaves and shoot time emerged. The used of IBA and BAP either alone or with the combination affected all of the observing variable. But has the different response in each variable. The IBA and BAP doesn't seem to affect the number of shoot which is, the objectives of this study is not achieve. Further study should be addressed to find out the more proper concentration of IBA and BAP to inducing the shoot and the growth of Java turmeric.

\section{ACKNOWLEDGMENT}

The author would like to thank the Ministry of Research, Technology, and Higher Education that has funded this research through the National Innovation System Research Incentive (Insentif Riset SINas) for fiscal year 2015, by title Seed Propagation Technology by In vitro to Support the Development of Medicinal Plants as Raw Material Medicine Industry in Java Corridor. 
REFERENCES
Anand P, Kunnumakkara AB, Newman RA, Aggarwal BB. 2007. Bioavailability of curcumin: problems and promises. Molecular Pharmaceutics 4:807-18.

Aznam N, Atun S 2016. Pharmacological test of herbal products from temulawak (Curcuma Xanthorhiza) as antihypercholesterol by in vivo. International Journal of Pharmacognosy and Phytochemical Research 8(5):807-811.

Bermawie N, Rahardjo, Wahyuno, Makmun. 2006. Status Teknologi Budidaya dan Pasca Panen Tanaman Kunyit Dan Temulawak Sebagai Penghasil Kurkumin. EDSUS Littro. 2(4):84-99.

BPOM. 2005. Peraturan Kepala Badan Pengawas Makanan tentang Kriteria dan tata laksana Pendaftaran Obat Tradisional, Obat Herbal Terstandar dan Fitofarmaka. BPOM Jakarta.

Devaraj S, Ismail S, Ramanathan S, Yam MF. 2013. In vivo toxicological investigations of standardized ethanolic extract of Curcuma xanthorrhiza Roxb. rhizome. Journal of Natural Product and Plant Resources. 3(1):67-73.

Hendaryono D, Wijayani A. 1994. Teknik Kultur Jaringan: Pengenalan dan Petunjuk Perbanyakan Tanaman Secara Vegetatif-Modern. Penerbit Kanisius. Yogyakarta

Hwang JK, Rukayadi Y. 2006. Challenges and opportunities in applying temulawak (Curcuma xanthorrhiza Roxb.) for industrial oral care products. Prosiding Seminar Nasional Himpunan Kimia Indonesia. Bogor (ID): Departemen Kimia FMIPA IPB dan Himpunan Kimia Indonesia, pp 2532.

Indah PN, Ermavitalini D. 2013. Induksi kalus daun nyamplung (Calophyllum inophyllum Linn.) pada

beberapa kombinasi konsentrasi 6-

Benzylaminopurine (BAP) dan 2,4Dichlorophenoxyacetic Acid (2,4-D). Jurnal Sains dan Seni Pomits. 2(1):E-1 - E-6

Madhulatha P, Anbalagan $M$, Jayachandaran $S$, Sakthivel N. 2004. Influence of liquid pulse treatment with growth regulators on In vitro propagation of banana (Musa sp. AAA). Plant Cell, Tissue and Organ Culture. 76:189-192.

Musfiroh I, Muchtaridi M, Muhtadi A, Diantini A, Hasanah AN, Udin LZ, Susilawati Y, Mustarichie R, Kartasasmita RE, Ibrahim S. 2013. Cytotoxicity studies of xanthorrhizol and its mechanism using molecular docking simulation and pharmacophore modelling. Journal of Applied Pharmaceutical Science. 3(06):007-015.

Oon SF, Nallappan M, Tee TT, Shohaimi S, Kassim NK, Sa'ariwijaya MSF, Cheah YH. 2015. Xanthorrhizol: a review of its pharmacological activities and anticancer properties. Cancer Cell International 15:100.

Patma U, Agustina LPP, Siregar L. 2013. Media tanam dan pemberian auksin asam asetat naftalen pada pembibitan aren (Arenga pinnata Merr.). Jurnal Online Agroteknologi. 1(2):1-10

Rabbani MG, Ali MH, Mondal MF. 1996. Effect of BAP and IBA on micropropagation of some banana cultivars. Bangladesh Horticulture. 25(1 dan 2):4752.

Rahayu S, Hadi WA. 2012. The effect of BAP and thidiazuron on in vitro growth of java turmeric (Curcuma xanthorrhiza Roxb.). ARPN Journal of Agricultural and Biological Sciences. 7(10):820-824.

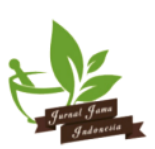

